\title{
High prevalence of syphilis among demobilized child soldiers in Eastern Congo: a cross-sectional study
}

Raphael Kabangwa Senga ${ }^{1}$ and Prosper Mukobelwa Lutala ${ }^{2^{*}}$

\begin{abstract}
Background: Syphilis, a known major public health issue for soldiers during periods of conflict, is exacerbated in the Democratic Republic of Congo due to widespread sexual violence. However, there has been no previous study to determine the extent of this problem. Therefore, we determined the prevalence of syphilis among young demobilized soldiers.

Methods: Screening of syphilis using the rapid plasma reagin test and the Treponema pallidum hemagglutination assay was conducted in three transit sites of soldier reintegration in 2005. The Fisher Exact probability test was used to compare results.

Results: The prevalence of syphilis was found to be 3.4\%, with almost equal distribution in respect to sex, location. Conclusion: Syphilis continues to be highly prevalent in demobilized child soldiers in Eastern Congo. Syphilis screening tests are recommended.
\end{abstract}

\section{Background}

Syphilis and to some extent other sexually transmitted infections (STIs) are a major public health issue for soldiers during periods of conflict. In the Democratic Republic of Congo (Congo), these have been exacerbated by widespread sexual violence. Child soldiers are particularly vulnerable due to several factors: incomplete maturation, low social conditions, use as sexual workers by superiors, and their promiscuous environment. During World Wars I and II and subsequent armed conflicts throughout the world, syphilis has played an unprecedented role in soldier morbidity [1]. The Congo, with almost two decades of armed conflicts, is characterized by widespread sexual violence [2,3]. In the Congo and other African countries, recruitment of child soldiers has been largely practiced despite its war-crime characterization as defined by the Rome Statute of the International Criminal Court [4].

\footnotetext{
* Correspondence: jolutprosper@yahoo.fr

${ }^{2}$ United Nations Volunteers, Central-East Zone, Health éducation Unit Compound, Lilongwe, P.O. Box 30135, Malawi and Département de Médicine de Famille, Université de Goma, 2 Avenue Himbi, Goma, Boite postale 204, Congo

Full list of author information is available at the end of the article
}

As a war nears its end, disarmament, demobilization, and reinsertion (DDR) of combatants is a compulsory post-conflict step. In the Congo, all child soldiers undergo this process, which allows soldiers who desire, or who are children, to return to civilian life. At the transit camp soldiers undergo compulsory syphilis testing. To prevent possible spread of the disease upon reintegration, those who test positive undergo treatment.

Despite a number of studies dealing with syphilis prevalence in various contexts, to our knowledge, little is known about syphilis prevalence in demobilized soldiers, and particularly in child soldiers. Therefore, we determined the prevalence of syphilis among this group in the Congo.

\section{Methods \\ Design population and sampling}

This cross-sectional study was conducted in three Transit and Reception Centers during DDR in Goma, Congo, between April 14 and June 14, 2005. Study subjects were young (extremes: 10 and 20 years old), newly-demobilized soldiers who, after spending some period in army/rebellion militias, were going through preparation for community integration. Some participants were also receiving 
vocational training. All participants were recruited by the national army or rebellion militia when they were less than 15 years old. Three hundred participants were contacted, and 163 volunteered to undergo screening for syphilis.

\section{Data collection}

After written informed consent was obtained from each participant and each participant underwent appropriate pretest counseling, venous blood was collected and transferred to the laboratory. Following identification and verification of the samples for conformity, the blood cells were centrifuged and sera were separated from cells immediately after clotting. Syphilis serostatus was determined by the rapid plasma reagin (Lampole Laboratories, Princeton, NJ., USA) test and the Treponema pallidum hemagglutination assay (Serodia1-TPHA; Fujirebio Inc., Tokyo, Japan), according to the manufacturers' instructions. Remaining sera were stored at $-20^{\circ} \mathrm{C}$. Results were considered positive if both tests were found to be reactive. Posttest counseling was provided by trained counselors irrespective of the results.

\section{Statistical analyses}

Descriptive statistics were generated by using the subjects' demographic characteristics, and results were presented as percentages. Data and associations between demographic characteristics and syphilis tests were analyzed using Fisher's Exact Test [5].

\section{Ethical considerations}

Ethical clearance to conduct the study was granted by the ethical review board of the University de Goma. Written informed consent for publication was sought and obtained from each patient or a relative before the sample of blood was collected.

\section{Results}

\section{Socio-demographic characteristics}

The sociodemographic characteristics of the study are presented in Table 1

A total of 263 participants, who were mostly males $(244 / 263 ; 89.7 \%)$, between the age of 15 and 18 years old (62.7\%), and from the Karibu C Transit and Reception Center (51\%), were recruited. (Table 1)

\section{Prevalence of syphilis}

Table 2 shows the prevalence of syphilis and its comparison across variables. The prevalence of syphilis was $3.4 \%$. The distribution of syphilis serology results did not show any difference in terms of residence location $(p=0.9049)$, sex of participants $(p=0.2341)$, but there was a difference between the age ranges $(p<0.0001)$ (Table 2).
Table 1 Socio-demographic data

\begin{tabular}{|c|c|c|}
\hline Variables & Frequency & Percent \\
\hline \multicolumn{3}{|l|}{ Sex of the participants } \\
\hline Males & 244 & 89.7 \\
\hline Females & 28 & 10.3 \\
\hline \multicolumn{3}{|l|}{ Age range (years) } \\
\hline $10-15$ & 67 & 25.5 \\
\hline $15-18$ & 165 & 62.7 \\
\hline$>18$ & 26 & 9.9 \\
\hline Missing values & 5 & 1.9 \\
\hline \multicolumn{3}{|l|}{ Participant location } \\
\hline Karibu CAJED* Transit and Reception Center & 134 & 51.0 \\
\hline $\begin{array}{l}\text { SOS Grand-Lacs Transit and Reception } \\
\text { Center }\end{array}$ & 69 & 26.2 \\
\hline Divas Transit and Reception Center & 60 & 22.8 \\
\hline Total & 263 & 100 \\
\hline
\end{tabular}

${ }^{*}$ Concert d'Actions pour Jeunes et Enfants Défavorisés.

\section{Discussion}

The prevalence of syphilis among young demobilized soldiers was found to be quite high at 3.4\% in Eastern Congo (Table 2). The results can be interpreted that child soldiers are at disproportionately higher risk of experiencing sexual violence at an early age.

While lower than the prevalence reported among soldiers in Ethiopia (16.7\%) [6], this prevalence was higher than that found among pregnant women in Kinshasa [7], and similar to victims of sexual violence in nearby SouthKivu province [8]. Reproductive health assessments of internally displaced women residing in camps, and counterparts residing in surrounding host communities, showed the syphilis prevalence to be 4 and $0.5 \%$, respectively. This may be a proxy of high syphilis prevalence in soldiers who reside nearby. Contrary to our results, surprisingly in a similar war-torn setting in Ibadan, Iran, syphilis prevalence was lower $(0.1 \%$, with genital ulcer prevalence of 1.9\%) [9]. Reasons are still unclear.

The higher prevalence in females, and in 16-18 yearolds soldiers (Table 2), needs cautious interpretation, because the number of girls is too low and sexual activity is intense at this age range. Furthermore, among people of a young age with limited sexual experience, the risk of STIs is high.

\section{Limitations}

This study must be interpreted in light of several limitations. Our investigations examined one STI, while groups in conflict settings are prone to a range of STIs. The role of ulcerative STIs in transmission of HIV could justify the current study. The nonrandom selection of our sample may not allow any generalization of our results. Some social/behavioral determinants that have a bearing in syphilis (and STI) acquisition, such as condom use, sexual 
Table 2 Prevalence of syphilis

\begin{tabular}{|c|c|c|c|}
\hline & Positive & Negative & p- (Fisher 2-tails) \\
\hline \multicolumn{4}{|l|}{ Participant's Locations } \\
\hline \multirow[t]{2}{*}{ CAJED Karibu Transit and Reception Center } & $4(3.0)$ & 130(97.0) & \\
\hline & & & 0.9040 \\
\hline Grand-Laces Transit and Reception Center & $3(4.3)$ & $66(96.7)$ & \\
\hline Divas Transit and Reception Center & $2(3.3)$ & $58(96.7)$ & \\
\hline \multicolumn{4}{|l|}{ Sex of participants } \\
\hline Males & $7(2.9)$ & 237(97.1) & 0.2341 \\
\hline Females & $2(7.1)$ & 26(92.9) & \\
\hline \multicolumn{4}{|l|}{ Ages ranges (in years) } \\
\hline $10-15$ & $0(0.0)$ & $67(100)$ & \\
\hline $15-18$ & $8(4.8)$ & 157(95.2) & $<0.0001$ \\
\hline$>18$ & $1(3.8)$ & 25(96.2) & \\
\hline Missing values & $5(100)$ & $0(0.0)$ & \\
\hline Total & $9(3.4)$ & $254(96.5)$ & \\
\hline
\end{tabular}

partner numbers, sexual intercourse type, and duty duration were beyond the scope of the current study and were not investigated. Lack of quality control could jeopardize the validity of the results.

Nonetheless, the association of rapid plasma reaginTreponema pallidum hemagglutination assay remains appropriate in the diagnosis of syphilis in our challenging work conditions in the Congo [10]. The World Health Organization advocated STI screening to control sexual transmitted infections in recent years, using simple rapid points of care targeting mainly high-risk groups in the community, such as military recruits and company employees [11], adolescents, and sex workers [12]. Early detection of symptomatic and asymptomatic infections is a key element in the public health package for STI control [13]. A recent meta-analysis of prenatal screening programs based on studies conducted in the United States and other countries found that low- and middleincome populations showed a reduction in the incidence of perinatal deaths and congenital syphilis in live-born infants after appropriate treatment [14].

\section{Conclusion}

The prevalence of syphilis in demobilized child soldiers was high in Goma, especially in 16- to 18-year-olds and in females. Efforts should be taken to generalize such screening to other demobilization sites and extend testing to other STIs, including HIV. A study including all sexual behavioral factors as well as the determinants of syphilis (and other STIs) in demobilized child soldiers is warranted in the near future.

\section{List of abbreviations used}

AMI-LABO: Appui Médical Intégré aux activités de laboratoire; CAJED: Concert d'Actions pour Jeunes et Enfants Défavorisés; DDR:

Disarmament, demobilization, and reinsertion; DOCS: Doctors on Call for
Service; HIV: Human immunodeficiency virus; STI: Sexually transmitted infection; TPHA: Treponema Pallidum haemagglutination Assay; UN Volunteers: United Nations volunteers; UNDP: United Nations Development Programme; UNICEF: United Nations Children's Fund; USA: United States of America.

\section{Acknowledgements and funding}

We are very grateful to all of the participants who consented to take part in this study. We are also grateful to UNICEF/Goma, who partially funded the tests conducted, and the AMI-Labo, who partially funded the remaining testing and the transportation cost for the samples from collection points to the laboratory. However, the two funding bodies did not play any role in the study design, collection, analysis, interpretation of data, writing of the manuscript, or decision to submit the manuscript for publication.

\section{Author details}

${ }^{1}$ Appui Médical Intégré Aux Activités de Laboratoire (AMI-LABO), 68 Golf Avenue, Goma, Boite postale 187, Congo and Département des Sciences de base, Université de Goma, 2 Avenue Himbi, Goma, Boite postale 204, Congo. 'United Nations Volunteers, Central-East Zone, Health éducation Unit Compound, Lilongwe, P.O. Box 30135, Malawi and Département de Médicine de Famille, Université de Goma, 2 Avenue Himbi, Goma, Boite postale 204, Congo.

\section{Authors' contributions}

RKS conceived the idea, collected the data, and gave input in the manuscript drafting. PML designed the study, analyzed and interpreted the data, and drafted the manuscript. All authors read and approved the final manuscript.

\section{Authors' details}

RKS: Graduate clinical biologist, lecturer at Département des sciences de base the school of Medicine (University of Goma), and director of the AMILabo, the provincial referral laboratory for the North Kivu province; Goma Congo/DRC.

PML: HIV Zonal supervisor/MOH Malawi and family physician Département de Médecine de Famille, Université de Goma.

\section{Competing interests}

The first author is one of the study's funders and the director of the AmiLabo (the laboratory that carried out the testing of all blood samples). However, the laboratory did not play any role in the conception, data collection, analysis, or reporting of the current research.

Received: 20 May 2011 Accepted: 6 September 2011 Published: 6 September 2011 
1. Brandt AM: The syphilis epidemic and its relation to AIDS. Science 1988 239:375-380.

2. Kalonda JCO: Sexual violence in the Democratic Republic of Congo: Impact on public health? Med Trop 2008, 68:576-578.

3. Longombe $\mathrm{AO}$, Claude KM, Ruminjo J: Fistula and traumatic genital injury from sexual violence in a conflict setting in Eastern Congo: case studies. Reprod Health Matters 2008, 16:132-141.

4. Children \& Parliament, spring/summer 23 Apr 1999, Col 1140-1202. [http://adc.bmj.com/content/81/5/461.full].

5. Joosse SA: Fisher's exact test. 2011 [http:// http://in-silico.net/statistics/ fisher_exact_test].

6. Kassu A, Mekonnen A, Bekele A, et al: HIV and syphilis infections among elderely people in Northwest Ethiopia. Jpn J Infect Dis 2004, 57:274-267.

7. Moleka RK, Smith JS, Atibu J, et al: Low prevalence of HIV and other selected sexually transmitted infections in 2004 in pregnant women from Kinshasa, the Democratic Republic of the Congo. Epidemiol Infect 2008, 136:1290-1296.

8. Mukwege DM, Nangini C: Rape with Extreme Violence: The New Pathology in South Kivu, Democratic Republic of Congo. PLoS Med 2009, 6:e1000204.

9. Ghorbani GHA, Mohamadi H, Esfahani AA: Prevalence of syphilis and Chlamydia trachomitis in soldiers. Journal of Military Medicine. 2009, 11(2):15-16

10. West B, Walraven G, Morison L, Brouwers J, Bailey R: Performance of the rapid plasma reagin and the rapid syphilis screening tests in the diagnosis of syphilis in field conditions in rural Africa. Sex Transm Infect 2002, 78:282-285.

11. Mayaud P, Mabey D: Approaches to the control of sexually transmitted infections in developing countries: old problems and modern challenges. Sex Transm Infect 2004, 80:174-182.

12. Mabey D, Peeling RW, Perkins MD: Rapid and simple point of care, diagnostics for STIs. Sex Transm Infect 2001, 77:397-8.

13. UNAIDS: The public health approach to STD control: UNAIDS Technical Update. UNAIDS Best Practice Collection: Technical Update Geneva: UNAIDS; 1998

14. Louden K: Syphilis Screening, Treatment Could Reduce Infant Deaths. Lancet Infect Dis, Published online June 15, 2011.

doi:10.1186/1752-1505-5-16

Cite this article as: Senga and Lutala: High prevalence of syphilis among demobilized child soldiers in Eastern Congo: a cross-sectional study. Conflict and Health 2011 5:16.

\section{Submit your next manuscript to BioMed Central and take full advantage of:}

- Convenient online submission

- Thorough peer review

- No space constraints or color figure charges

- Immediate publication on acceptance

- Inclusion in PubMed, CAS, Scopus and Google Scholar

- Research which is freely available for redistribution

Submit your manuscript at www.biomedcentral.com/submit
C Biomed Central 